\title{
FIRST OBSERVATIONS OF SHORTFINNED ANGUILLA BICOLOR BICOLOR AND LONGFINNED ANGUILLA MARMORATA SILVER EELS IN THE REUNION ISLAND.
}

\author{
T. ROBINET, E. FEUNTEUN \\ UMR CNRS 6553 EcoBio, Université de Rennes I, Avenue du Général Leclerc, \\ 35042 RENNES Cedex, France. E-mail : tony.robinet@univ-rennes1.fr
}

\section{ABSTRACT}

Silver stage specimens of Anguilla bicolor bicolor and A. marmorata were fished with a keep net in an estuary of the Reunion island (Indian ocean). Such silver anguillids eels have not been pointed out since the years 1957-1958 in South Africa. This short note gives the first morphometric observations of these specimens, before starting histological, endocrinological and otolithometrical analysis, that should contribute to a have a better undestanding of these tropical eels species biological cycle.

\section{PREMIÈRES OBSERVATIONS D'ANGUILLES ARGENTÉES ANGUILLA BICOLOR BICOLOR ET ANGUILLA MARMORATA DANS L'ÎLE DE LA RÉUNION.}

\section{RÉSUMÉ}

Des anguilles Anguilla bicolor bicolor et $A$. marmorata au stade argenté ont été pêchées à la nasse dans un estuaire de l'île de la Réunion (océan Indien). De telles anguilles argentées n'avaient pas été signalées depuis les années 1957-58 en Afrique du Sud. Cette courte note présente les premières observations morphométriques de ces spécimens, avant d'entreprendre des analyses histologiques, endocrinologiques et otolithométriques, qui devraient contribuer à une meilleure connaissance du cycle biologique de ces espèces tropicales. 


\section{INTRODUCTION}

Genus Anguilla has 15 species around the world (CASTLE and WILLIAMSON, 1974). Its original biological cycle contains two migrations and for each metamorphis occurs, the first trophic (leptocephalus and glass-eels stages, see LECOMTE-FINIGER, 1994), and the second genesic (silver eels, see FONTAINE Y.A., 1994). The silvering induces physiological and morphometrical drastic changes (see FONTAINE M., 1975; THOMPSON and SARGENT, 1978; KLECKNER and KRUEGER, 1981; PANKHURST, 1982a, b, c; PANKHURST and LITHGOE, 1982; FONTAINE Y.A., 1989). On the 15 species the genus counts, 12 have a known silver stage $(A$. anguilla, $A$. rostrata, $A$. japonica, A. australis, A. bicolor bicolor, A. dieffenbachii, A. marmorata, A. mossambica, A. megastoma, $A$. nebulosa labiata, $A$. obscura and $A$. reinhardtii; see TESCH, 1928; CAIRNS, 1941; BERTIN, 1942; CALLEMAND, 1943; HOBBS, 1947; BIGELOW and SCHROEDER, 1953; D'ANCONA, 1960; JUBB, 1961; BURNETT, 1969; TODD, 1974, 1981a, 1981b; COLOMBO et al., 1984; SLOANE, 1984; MARQUET, 1987; LE BELLE et al., 1988; FONTAINE, 1994; JELLYMAN and TODD, 1998; AOYAMA et al., 1999). For all these species, following the physiological changes, the silver stage can be recognized by typical external marks: changes in skin colour (back is darker due to melanin, sides and belly are white / silver due to purine, PANKHURST and LYTHGOE, 1982), development of lateral line (ZACCHEI and TAVOLARO, 1988), increase in the eye size (D'ANCONA, 1927; TODD, 1981a; PANKHURST, 1982a), and increase in the pectoral fins (MARQUET, 1987). This silver stage is still unknown for the 3 species left $(A$. borneensis, $A$. celebesensis, and $A$. interioris) and 2 other subspecies ( $A$. bicolor pacifica and $A$. nebulosa labiata).

A first specimen of $A$. bicolor bicolor silver female was found in September 1957 in the Zululand, South Africa ( $64 \mathrm{~cm}$ for $0.51 \mathrm{~kg}$; JUBB, 1961), and any specimen hasn't been found since, according to our knowledge. Since SCHMIDT (1927) pointed out silver males of $A$. marmorata in Tahiti ( 71 and $83 \mathrm{~cm}$ for 1.2 and $1.9 \mathrm{~kg}$ respectively), only one mature specimen (female, $134 \mathrm{~cm}$ for $9.98 \mathrm{~kg}$ ) has been found in February 1958 in the Sundays River (South Africa; JUBB, 1961). Forty three years later, we found a second A. bicolor bicolor and a fourth $A$. marmorata mature specimens in the streams of the Reunion Island, near Madagascar. This paper relates the first morphometric observations of these $A$. bicolor bicolor and $A$. marmorata silver eels, two of the fourth anguillid species which live in the rivers of the Reunion island (KEITH et al., 1999).

\section{MATERIAL AND MORPHOMETRIC DATA}

The Reunion island $\left(21^{\circ} \mathrm{S} 56^{\circ} \mathrm{E}\right)$ is a recent volcanic formation in the South-West Indian ocean. The intertropical weather drops as far as 5 m.year ${ }^{-1}$, so rivers are subjected to exceptional flow rises, particularly from December to April, preventing stenohaline freshwater species to settle in the hydrosystem (KIENER, 1981). The Roches river is a small catchment $\left(24.5 \mathrm{~km}^{2}\right.$, Figure 1$)$ in the Reunion island. We installed a keep net in the estuary, $4 \mathrm{~m}$ from the right bank and $100 \mathrm{~m}$ from the seawater. Keep net, facing the sea, was collected every day from the 15.02 to the 28.03.2001. Anguilla bicolor bicolor and A. marmorata silver eels were caught respectively on the 06.03 and the 07.03 at the twilight, when 81 and $89 \%$ of the moon was visible. 


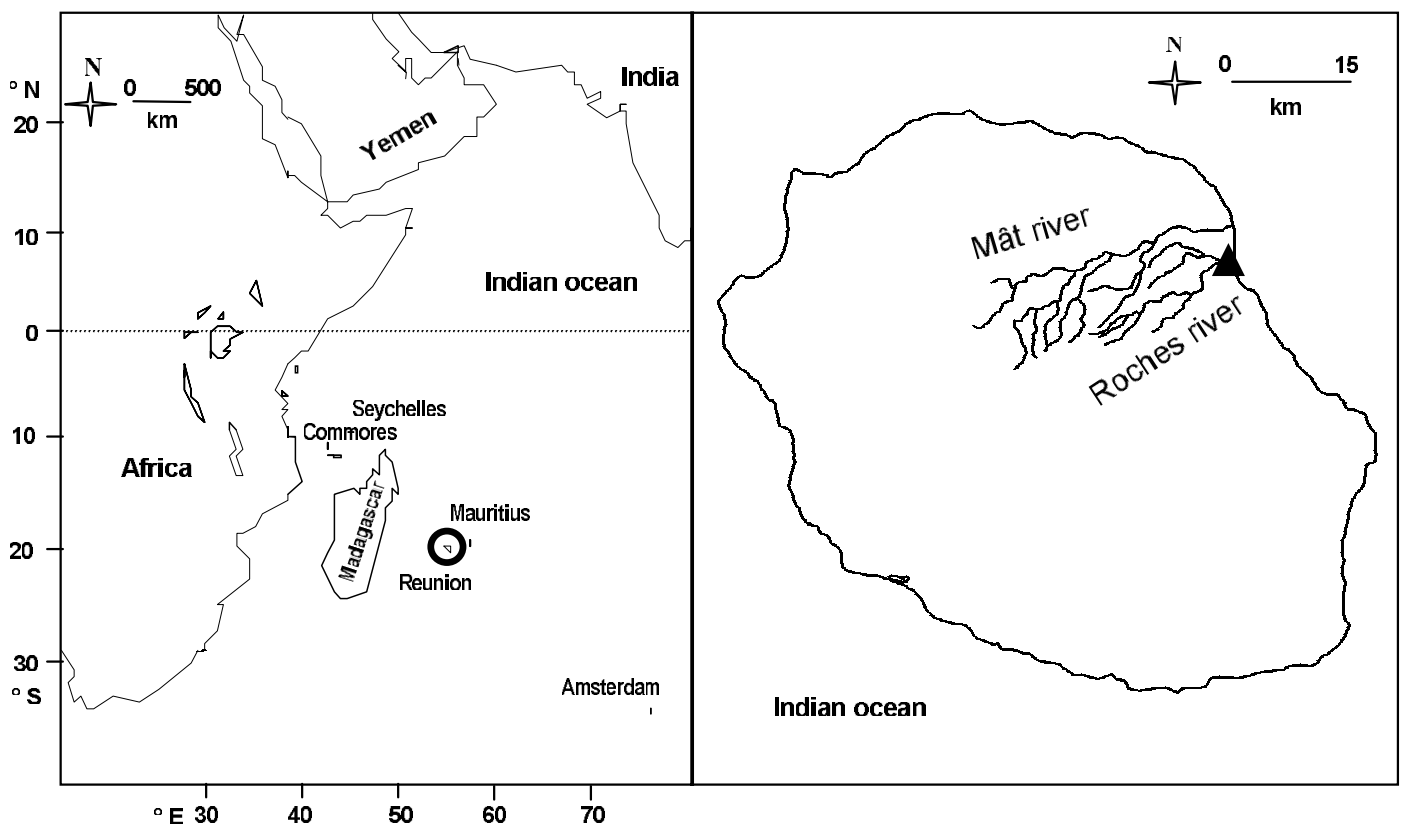

Figure 1

Localisation of the Reunion island and catch sites $(\Delta)$ on the Roches river. The yellow eels $A$. marmorata for ocular index comparisons were caught in the Mât river.

Figure 1

Localisation de l'île de la Réunion et des sites de capture $(\Delta)$ sur la rivière des Roches. Les anguilles jaunes $A$. marmorata pour les comparaisons d'indices oculaires ont été pêchées dans la rivière du Mât.

The shortfinned eel $A$. bicolor bicolor (McCLEALLAND, 1844) was $744.0 \mathrm{~mm}$ long for a weight of $661.3 \mathrm{~g}$ (Table I). The ratio between anal-dorsal distance and body length was $2.1 \%$, and the plained back of the eel made us sure it was this species, according to EGE (1939). This specimen was a female, according to its high gonadosomatic ratio (RGS $=6.78 \%$ ). The back was dark-grey until the dorsal sides (Figure 2). The ventral sides became silvered-yellow until the belly, and the belly was white, lightly silvered from the mouth to a clear silver colour at the tail. Its both pectoral fins were golden near the pectoral joint, and being darker until black on the distal part. The lateral line, regularly interrupted by black points (neuromasts), was present $5 \mathrm{~mm}$ bellow the separation of the dark dorsal sides and the silver-golden ventral sides. So the silver colour came relatively high on the sides, above the lateral line. Pupils were both black, iris was golden and circled in a greyblue colour.

The longfinned and marbled eel A. marmorata (QUOY and GAIMARD, 1824) was $708.0 \mathrm{~mm}$ long for a weight of $773.7 \mathrm{~g}$ (Table I). The ratio between anal-dorsal distance and body length was $17.4 \%$, and the marbled back of the eel made us sure it was this species, according to EGE (1939). Its RGS (1.56\%) showing a low value in comparison with the high OI, and after a macroscopical exam, we are inclined to think, subject to further histological exams, that this specimen was a mature male. The back, as the dorsal sides, were finely marbled of yellow on a dark-brown background (Figure 2). The dorsal sides coloration stopped $5 \mathrm{~mm}$ above the lateral line, where started the really golden 
ventral sides. Belly was white near the head and silver-golden near the tail. As A. bicolor bicolor, its both pectoral fins were golden close to the pectoral joint, and being darker untill black on the distal part. The lateral line was lower than the side colour transition, less marked than $A$. bicolor bicolor, and only represented by neuromasts. Pupils were both black, iris was golden and circled in a grey-blue colour.

\section{Table I}

Morphometrics of the silver eels A. bicolor bicolor and A. marmorata. Total Length (TL), Dorsal Lenght (DL), Anal Length (AL), Anodorsal Ratio (\% AD), body and gonads weights, GonadoSomatic Ratio (\% RGS), left and right pectoral fins Width (W) and High $(\mathrm{H})$, left and right eyes Horizontal $(\mathrm{H})$ and Vertical $(\mathrm{V})$ diameters, Ocular Index (OI, PANKHURST, 1982a).

\section{Tableau I}

Données morphométriques des anguilles argentées $A$. bicolor bicolor et A. marmorata. Longueur Totale (TL), Dorsale (DL) et Anale (AL), rapport AnoDorsal (\% AD), poids du corps et des gonades, Rapport GonadoSomatique (\% RGS), largeur (W) et Hauteur $(\mathrm{H})$ de nageoire pectorale gauche et droite, diamètre Horizontal (H) et Vertical (V) de l'œil gauche et droit, Index Oculaire (OI, PANKHURST, 1982a).

\begin{tabular}{|c|c|c|c|c|c|c|c|c|c|c|}
\hline & TL & & $A L$ & $\% A D$ & We & ght (g) & Pectc & al fins & & yes \\
\hline & & $(\mathrm{mm})$ & & & $\begin{array}{l}\text { whole } \\
\text { body }\end{array}$ & $\begin{array}{c}\text { gonads } \\
\text { (\% RGS) }\end{array}$ & left & right & left (OI) & right (OI) \\
\hline $\begin{array}{l}\text { A. bicolor bicolor } \\
\text { (female) }\end{array}$ & 744.0 & 287.0 & 302.5 & 2.1 & 661.3 & $\begin{array}{c}44.8 \\
(6.78)\end{array}$ & $\begin{array}{l}W: 38.1 \\
H: 27.9\end{array}$ & $\begin{array}{l}W: 38.8 \\
H: 29.1\end{array}$ & $\begin{array}{l}H: 7.7 \\
V: 7.4 \\
(6.02)\end{array}$ & $\begin{array}{l}H: 8.7 \\
V: 7.4 \\
(5.72)\end{array}$ \\
\hline $\begin{array}{l}\text { A. marmorata } \\
\text { (male) }\end{array}$ & 708.0 & 175.0 & 298.0 & 17.4 & 773.7 & $\begin{array}{c}12.0 \\
(1.56)\end{array}$ & $\begin{array}{l}W: 43,6 \\
H: 21,0\end{array}$ & $\begin{array}{l}W: 42,8 \\
H: 21,9\end{array}$ & $\begin{array}{l}H: 10,6 \\
V: 11,0 \\
(12.31)\end{array}$ & $\begin{array}{l}H: 10,3 \\
V: 10,6 \\
(11.53)\end{array}$ \\
\hline
\end{tabular}

\section{DISCUSSION}

The shortfinned eel $A$. bicolor bicolor, distinguished from the other subspecies A. bicolor pacifica (EGE, 1939), is exclusively reported in the Indian Ocean, in the West part continent and islands (EGE, 1939; JESPERSEN, 1942; CASTLE, 1984, 1986; MARQUET et al., 1997), as in the East part (Indian coast, described as $A$. bleekeri, A. cantori, A. dussumieri and A. malabarica, KAUP, 1856; BAUCHOT et al., 1993). These observations about its silver stage, the second after JUBB (1961), give further and original observations about this poorly known stage. Its ocular index $(\mathrm{OI}=6.02$ and 5.72$)$ and gonadosomatic ratio (RGS $=6.58$ ) are sufficiently high to believe it is approaching sexual maturity. We haven't got any OI or RGS references for yellow eels of $A$. bicolor bicolor, because of the infrequency of this species in the Reunion's rivers. 

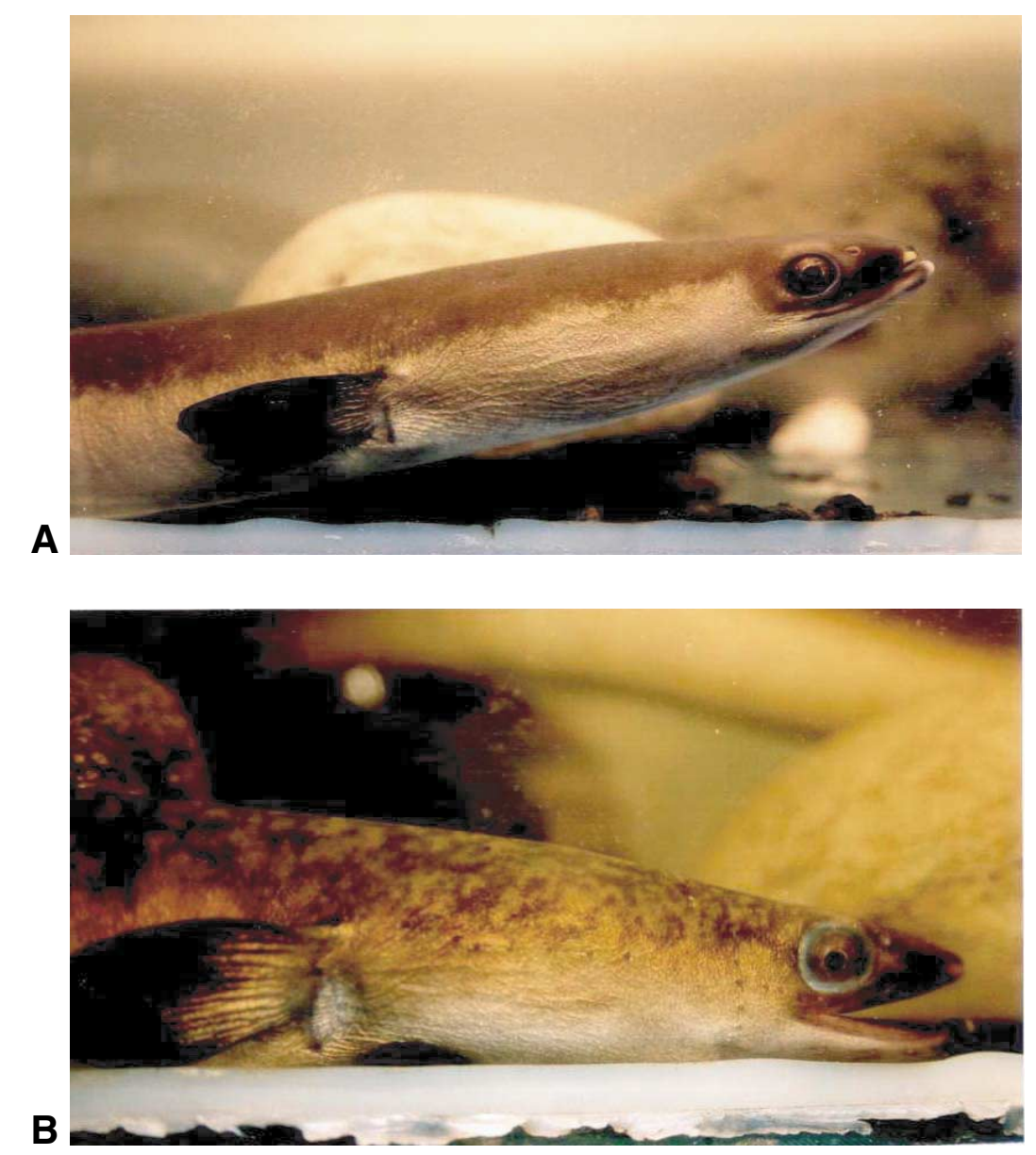

\section{Figure 2}

Pictures of the silver eels A. bicolor bicolor (A) and A. marmorata (B).

\section{Figure 2}

Clichés des anguilles argentées $A$. bicolor bicolor (A) et $A$. marmorata (B).

The longfinned and " giant marbled eel " A. marmorata is the eel species with the widest repartition area, from Polynesia (Gambier Islands) to the South-East African coast (EGE, 1939; NISHI and IMAI, 1969; KIENER, 1981; MARQUET and LAMARQUE, 1986; JELLYMAN, 1987; MARQUET and GALZIN, 1991; MARQUET, 1992; WILLIAMSON and BOËTIUS, 1993; TZENG et al., 1995; BUDIMAWAN, 1997; MARQUET et al., 1997). Its ocular index $(\mathrm{OI}=12.31$ and 12.53$)$ are typical of others Anguilla sp. mature specimens ready to quit freshwaters. Its $\mathrm{Ol}$ are compared to OI of yellow eels $A$. marmorata (Figure 3 ), fished in the Mât river (Figure 1). For a total length between 200 and $600 \mathrm{~mm}$, yellow eels have an OI lower than 6.0, except two big yellow specimens $(\mathrm{OI}=7.19$ and 7.49$)$. The A. marmorata silver eel has an $\mathrm{Ol}$ near two times bigger than those hypothetical same length yellow eels, and could therefore be considered as "sexually maturing adult " according to previous works on $A$. anguilla (PANKHURST, 1982a). Such a difference between yellow and silver stage eyes diameter for a given body length is not observed for the pectoral length of the present specimens. 


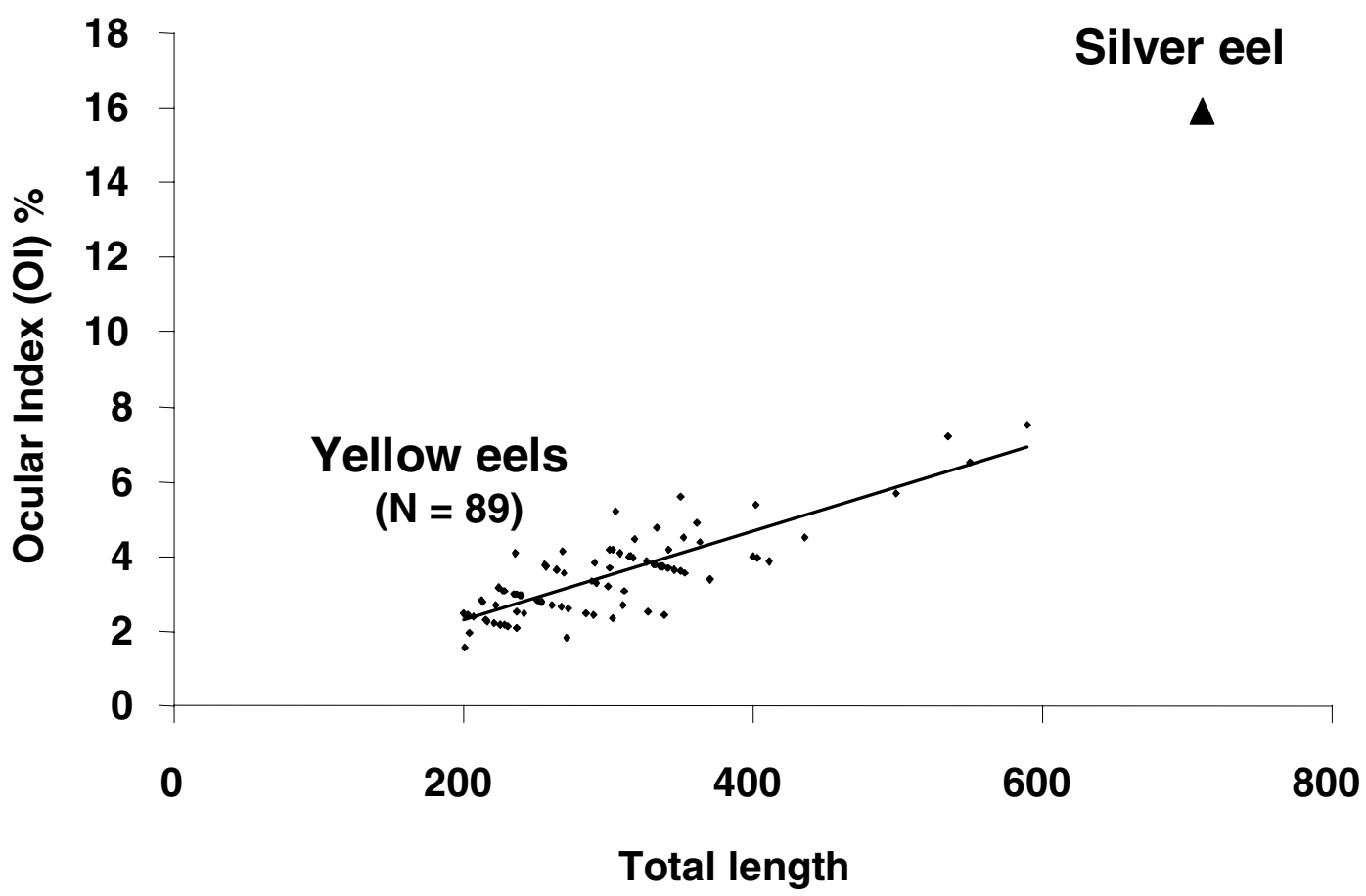

Figure 3

Evolution of the ocular index (PANKHURST, 1982a) with the total length of $A$. marmorata in the Mât river (Reunion island). The silver eel $(\mathrm{OI}=15.93 \%)$ is clearly out of the yellow eels adjusted line $\left(y=0.0119 x-0.1044\right.$ and $\left.R^{2}=0.6967\right)$. The linear series in yellow eels index are due to the measurement precision of eye diameter $(0.5 \mathrm{~mm})$.

Figure 3

Evolution de l'indice oculaire (PANKHURST, 1982a) avec la longueur totale de $A$. marmorata dans la rivière du Mât (lle de la Réunion). L'anguille argentée $(\mathrm{OI}=15,93 \%)$ est largement en dehors de la ligne ajustée des anguilles jaunes $\left(y=0,0119 x-0,1044\right.$ et $\left.R^{2}=0.6967\right)$. Les séries linéaires visibles dans les indices d'anguilles jaunes sont dues à la précision des mesures $(0,5 \mathrm{~mm})$.

According to JESPERSEN (1942), a first spawning area of $A$. bicolor bicolor is expected to locate in South-West Sumatra deep waters, confirmed by ARAII et al. (1999). According to the present findings, and to the regional currents, a second spawning area for the Indian ocean may locate around the North-East waters of Madagascar. Concerning A. marmorata, at least five distinct populations are known today, all emerged from an Indonesian ancestral population shared with $A$. reinhardtii, spread on the actual repartition area by the circum equatorial current, between 100 and 50 million years ago (TSUKAMOTO and AOYAMA, 1998). These findings will be further developed by an histological exam of gonads, sexual hormones concentrations measurements in plasma and pituitary, muscle lipid rate and bones calcium measurements, and otolithometric readings. These analysis should clarify the $A$. bicolor bicolor and $A$. marmorata life history in this region, particularly their silvering metamorphosis, and, in comparison with glass-eels otolithometric data, should also give a clue on the distance from the Reunion island of their respective spawning area. 


\section{REFERENCES}

AOYAMA J., HISSMAN K., YOSHINAGA T., SASAI S., UTO T., UEDA H., 1999. Swimming depth of migrating silver eels Anguilla japonica released at seamounts of the West Mariana Ridge, their estimated spawning sites. Mar. Ecol. Prog. Ser., 186, 265-269.

ARAÏ T., LIMBONG D., OTAKE T., TSUKAMOTO K., 1999. Metamorphosis and inshore migration of tropical eels Anguilla spp. in the Indo-Pacific. Mar. Ecol. Prog. Ser., 182, 283-293.

BAUCHOT M.L., DESOUTTER M., CASTLE P.H.J., 1993. Catalogue critique des types de poissons du Muséum National d'Histoire Naturelle. (suite) Ordre des Anguilliformes et des Saccopharyngiformes. Cybium, 17 (2), 91-151.

BERTIN L., 1942. Les Anguilles. PAYOT (ed.), Paris, 218 p.

BIGELOW H.B., SCHROEDER W.C., 1953. Fishes of the Gulf of Maine. Fishery Bull. Fish. Wildl. Serv. U.S., 53 (74), 1-577.

BUDIMAWAN, 1997. The early life history of the tropical eel Anguilla marmorata (Quoy and Gaimard, 1824) from four Pacific estuaries, as revealed from otolith microstructural analyses. Journal of Applied Ichthyology, 13, 57-62.

BURNET A.M.R., 1969. Migrating eels in a Canterbury river, New Zealand. New Zealand Journal of Marine and Freshwater Research, 3, 230-244.

CAIRNS D., 1941. Life-history of the two species of New Zealand fresh-water eel. Part I. Taxonomy, age and growth, migration, and distribution. New Zealand Journal of Science and Technology, 23, 53-72.

CALLEMAND O., 1943. L'anguille européenne (Anguilla anguilla L.). Les bases physiologiques de sa migration. Ann. Inst. Oceanogr., 21, 361-440.

CASTLE P.H.J, 1984. Anguillidae. In : FAO Species Identification Sheets for Fishery Purposes. Western Indian Ocean (Fishing Area 51), FISCHER W. and BIANCHI G., Eds., 1, 3 p. +5 fiches.

CASTLE P.H.J, 1986. Anguillidae. In: Smiths' Sea Fishes, SMITH M.M. and HEEMSTRA P.C., Eds., Springer Verlag., 160-161.

CASTLE P.H.J., WILLIAMSON G.R., 1974. On the validity of the freshwater eel species Anguilla ancestralis Ege from Celebes. Copeia, 2, 569-570.

COLOMBO G, GRANDI G., ROSSI R., 1984. Gonad differenciation and body growth in Anguilla anguilla L. J. Fish. Biol., 24, 215-228.

D'ANCONA U., 1927. Richerche sull'ingrandimento dell'occhio dell'Anguilla in rapporto alla maturita sessuale e considerazioni sul suo significata biologico. R. C. Acad. Nineci., 5 (6), 360-363.

D'ANCONA U., 1960. The Life-cycle of the atlantic eel. Symposia of the zoological Society of London, 1, 61-77.

EGE V., 1939. A revision of the genus Anguilla Shaw: a systematic, phylogenetic and geographical study. Dana Rep., 16 (3), 256 p.

FONTAINE M., 1975. Physiological mechanisms in the migration of marine and amphihaline fish. Adv. Mar. Biol., 13, 241-355.

FONTAINE Y.A., 1989. Les anguilles : migration et reproduction. Oceanis, 15, 197-206.

FONTAINE Y.A., 1994. L'argenture de l'anguille : métamorphose, anticipation, adaptation. Bull. Fr. Pêche Piscic., 335, 171-185.

HOBBS D.F., 1947. Migrating eels in Lake Ellesmere. Transactions of the Royal Society of New Zealand, 77 (5), 228-232.

JELLYMAN D.J., 1987. Review of the Marine Life History of Australasian Temperate Species of Anguilla. Am. Fish. Soc. Sympos., 1 (Common strategies of anadromous and catadromous fishes), 276-285.

JELLYMAN D.J., TODD P.R., 1998. Why are migrating male shortfinned eels (Anguilla australis) in Lake Ellesmere, New Zealand, getting smaller but not younger? Bull. Fr. Pêche Piscic., 349, 141-152.

JESPERSEN P., 1942. Indo-Pacific Leptocephalids of the genus Anguilla: systematic and biological studies. Dana Report n²2, RETZELS C.A. (ed.), Copenhagen, 13-103. 
JUBB R.A., 1961. The freshwater eels (Anguilla spp.) of Southern Africa: An introduction to their identification and biology. Ann. Cape Prov. Mus., 1, 15-48.

KAUP J.J., 1856. Catalogue of the apodal fish in the collection of the British Museum. London. Cat. Apodal Fish, 22 (1), 1-163.

KEITH P., VIGNEUX E., BOSC P., 1999. Atlas des poissons et crustacés d'eau douce de la Réunion. Patrimoines naturels (M.N.H.N./S.P.N.), 39, 136 p.

KIENER A., 1981. Etude des problèmes piscicoles des eaux intérieures de la Réunion. Rapport CEMAGREF Aix en Provence, Section Qualité des eaux - Pêche et pisciculture, Etude $\mathrm{n}^{\circ} 25,140 \mathrm{p}$.

KLECKNER R.C., KRUEGER W.H., 1981. Changes in swimblader retial morphology in Anguilla rostrata during premigration metamorphosis. J. Fish. Biol., 18, 596-597.

LE BELLE N., DUFOUR S., MARQUET G., KERDELHUE B., FONTAINE Y.A., 1988. Etat sexuel et axe gonadotrope hypothalamo-hypophysaire chez les trois espèces d'Anguilles de Tahiti (Anguilla marmorata, A. megastoma et $A$. obscura). Bull. Mus. Natn. Hist. Nat., Paris, $4^{\mathrm{e} e}$ série, 10 (section A, $n^{\circ} 1$ ), 147-160.

LECOMTE-FINIGER R., 1994. The early life of the European eel. Nature, 370, 424.

McCLELLAND J., 1844. Apodal fishes of Bengal. J. Nat. Hist. Calcutta, 151-226.

MARQUET G., 1987. Périlogie des anguilles de Tahiti-Moorea en Polynésie Française. Thèse de Doctorat E.P.H.E., 151 p.

MARQUET G., 1992. L'étude du recrutement et de la physiologie des anguilles de Polynésie Française permet-elle de cerner leur aire de ponte ? Bulletin de l'Institut Océanographique, Monaco, 10 (spécial), 129-147.

MARQUET G., LAMARQUE P., 1986. Acquisitions récentes sur la biologie des anguilles de Tahiti et de Moorea (Polynésie française) : A. marmorata, A. megastoma, A. obscura. Vie Milieu, 36 (4), 311-315.

MARQUET G., GALZIN R., 1991. The eels of French Polynesia: Taxonomy, distribution and biomass. La mer, 29, 8-17.

MARQUET G., SERET B., LECOMTE-FINIGER R., 1997. Inventaires comparés des poissons des eaux intérieures de trois îles océaniques tropicales de l'Indo-Pacifique (La Réunion, La Nouvelle-Calédonie et Tahiti). Cybium, 21 (suppl. 1), 27-34.

NISHI G., IMAI S., 1969. On the juvenile of Anguilla marmorata Quoy et Gaymard in Yakushima (Yaku Island). Its ecology and morphology. Mem. Fac. Fish. Kagoshima Univ., 18, 65-76.

PANKHURST N.W., 1982a. Relation of visual changes to the onset of sexual maturation in the European eel Anguilla anguilla (L.). J. Fish. Biol., 21, 127-140.

PANKHURST N.W., 1982b. Changes in body musculature with sexual maturation in the European eel, Anguilla anguilla (L.). J. Fish. Biol., 21, 417-428.

PANKHURST N.W., 1982c. Changes in the skin-scale complex with sexual maturation in the European eel, Anguilla anguilla (L.). J. Fish. Biol., 21, 549-561.

PANKHURST N.W., LYTHGOE J.N., 1982. Structure and colour of the integument of the European eel Anguilla anguilla (L.). J. Fish. Biol., 21, 279-296.

QUOY J.R.C., GAIMARD J.P., 1824. Description des Poissons. Chapitre IX. In : Voyage autour du Monde de L. Freycinet, exécuté sur les corvettes de L. M. «L'Uranie » et "La Physicienne », pendant les années 1817, 1818, 1819 et 1820. Voyage Uranie, Zool., Paris., 1-328.

SCHMIDT J., 1927. Les anguilles de Tahiti. La Nature, Paris, 57-65.

SLOANE R.D., 1984. Preliminary Observations of Migrating Adult Freshwater Eels (Anguilla australis australis Richardson) in Tasmania. Aust. J. Mar. Freshw. Res., 35, 471-476.

TESCH J.J., 1928. On sex and growth investigations of the freshwater eel in Dutch waters. J. Cons. Perm. Int. Explor. Mer, 3, 52-69.

THOMPSON A.J., SARGENT J.R., 1978. Changes in the levels of chloride cells and (Na-K) dependant ATPase in the gills of yellow and silver eels adapting to seawater. J. Exp. Zool., 200, 33-40.

TODD P.R., 1974. Studies on the reproductive biology of New Zealand freshwater eels. Thèse de Doctorat Ph.D., Université Victoria de Wellington, $330 \mathrm{p}$. 
TODD P.R., 1981a. Morphometric changes, gonad histology, and fecundity estimates in migrating New Zealand freshwater eels (Anguilla spp.). New Zealand Journal of Marine and Freshwater Research, 15, 155-170.

TODD P.R., 1981b. Timing and periodicity of migrating New Zealand freshwater eels (Anguilla spp.). New Zealand Journal of Marine and Freshwater Research, 15, 225-235.

TSUKAMOTO K., AOYAMA J., 1998. Evolution of freshwater eels of the genus Anguilla: a probable scenario. Environmental Biology of Fishes, 52, 139-148.

TZENG W.N., CHENG P.W., LIN F.Y., 1995. Relative abundance, sex ratio, population structure of japanese eel Anguilla japonica in Tanshui River system of northern Taiwan. Journal of Fish Biology, 46, 183-201.

WILLIAMSON G.R., BOËTIUS J., 1993. The Eels Anguilla marmorata and A. Japonica in the Pearl River, China, and Hong Kong. Asian Fisheries Sciences, 6, 129-138.

ZACCHEI A.M., TAVOLARO P., 1988. Lateral line system during the life cycle of Anguilla anguilla L. Boll. Zool., 3, 145-153. 
